\title{
Psychosocial care network: managers' perception and tensions of the field
}

\author{
Rede de atenção psicossocial: percepção de gestores e tensionamentos do campo \\ Red de atención psicosocial: percepción de gerentes y tensiones del campo
}

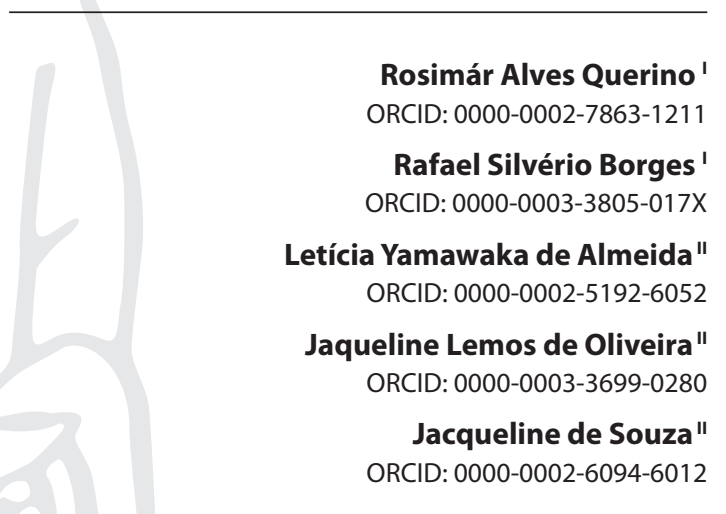

'Universidade Federal do Triângulo Mineiro. Uberaba, Minas Gerais, Brazil.

"Universidade de São Paulo. Ribeirão Preto, São Paulo, Brazil.

How to cite this article: Querino RA, Borges RS, Almeida LY, Oliveira JL, Souza J. Psychosocial care network: perception of managers and tensioning of field.

Rev Bras Enferm. 2020;73(Suppl 1):e20180844. doi: http://dx.doi.org/10.1590/0034-7167-2018-0844

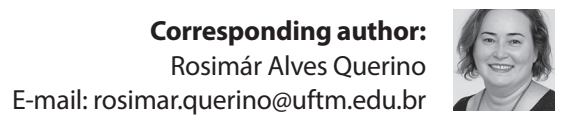

EDITOR IN CHIEF: Antonio José de Almeida Filho ASSOCIATE EDITOR: Rafael Silva

Submission: 09-02-2019

Approval: 11-21-2019

\begin{abstract}
Objective: to analyze the perception of workers and managers about the psychosocial care network in a medium-sized municipality in the inlands of the state of Minas Gerais. Method: qualitative, descriptive and exploratory study involving twelve participants from different points of the network. The semi-structured interviews were analyzed in the light of Pierre Bourdieu's framework of constructionist structuralism. Results: the actions offered by the services were based on the perspectives of resocialization, user embracement, group and multiprofessional care, and on approaches to harm reduction, recreation and daily organization. These were configured as the network resources/capital. Tensions were identified in family embracement and in relationships between families and users, as well as in the prejudice towards people with mental disorders. Final considerations: the social agents were willing to contribute to processes of change in order to overcome the focus on specialties, the lack of training of some teams, lack of infrastructure and of some components, especially those related to leisure and community life.
\end{abstract}

Descriptors: Mental Health Services; Health Services Research; Deinstitutionalization; Mental Health Care; Mental Health.

\section{RESUMO}

Objetivo: analisar a percepção de trabalhadores e gestores sobre a rede de atenção psicossocial em município de médio porte do interior de Minas Gerais. Método: estudo qualitativo, descritivo e exploratório envolvendo doze participantes dos diferentes pontos da rede. As entrevistas semiestruturadas foram analisadas com o referencial do estruturalismo construcionista de Pierre Bourdieu. Resultados: as ações oferecidas pelos serviços estavam pautadas na perspectiva de ressocialização, acolhimento, atendimento grupal, multiprofissional, bem como abordagens de redução de danos, recreação e organização do cotidiano e se configuraram em recursos/capitais da rede. Foram identificadas tensões no acolhimento das famílias e nas relações entre famílias e usuários, além do preconceito em relação à pessoa com transtorno mental. Considerações finais: os agentes sociais mostraram-se dispostos a contribuir em processos de mudanças para superar o foco nas especialidades, a falta de capacitação de algumas equipes, falta de infraestrutura e de alguns dispositivos, sobretudo aqueles relacionados ao lazer e convivência.

Descritores: Serviços de Saúde Mental; Pesquisa sobre Serviços de Saúde; Desinstitucionalização; Assistência à Saúde Mental; Saúde Mental.

\section{RESUMEN}

Objetivo: analizar la percepción de los trabajadores y gerentes sobre la red de atención psicosocial en un municipio de tamaño mediano en el interior de Minas Gerais. Método: investigación cualitativa, descriptiva y exploratoria con doce participantes de diferentes puntos de la red. Las entrevistas semiestructuradas se analizaron con el marco teórico referencial de estructuralismo construccionista de Pierre Bourdieu. Resultados: las acciones ofrecidas por los servicios se basaron en la perspectiva de resocialización, acogida, atención grupal y multiprofesional, así como en enfoques de reducción de daños, recreación y organización diaria y se configuraron en recursos/capital de la red. Se identificaron tensiones en la acogida de las familias y en las relaciones entre familias y usuarios, así como en el prejuicio hacia las personas con trastornos mentales. Consideraciones finales: los agentes sociales estaban dispuestos a contribuir a los procesos de cambio para superar el enfoque en las especialidades, la falta de capacitación de algunos equipos, la falta de infraestructura y de algunos componentes, especialmente aquellos relacionados con el ocio y la convivencia. Descriptores: Servicios de Salud Mental; Investigación de Servicios de Salud; Desinstitucionalización; Atención de la Salud Mental; Salud Mental. 


\section{INTRODUCTION}

Along with the mental health services reform and efforts to change the logic of care in this area, was recognized the magnitude of the global burden of mental disorders and the need for integrated and intersectoral responses ${ }^{(1-3)}$. The proposed organization of mental health services under the network logic is one of the strategies to broaden the care access and change the focus of the disease to the psychosocial needs of people with mental disorders ${ }^{(4)}$.

Such a network should be structured with points of care focused on both health care and social reintegration of individuals and families ${ }^{(2,4)}$. This proposal corroborates the World Health Organization (WHO) recommendations ${ }^{(2)}$ of consolidation of universal health systems from an integral, interprofessional perspective, with priority of community spaces.

The recognition of the Psychosocial Care Network as one of the priority thematic networks by the Brazilian state ${ }^{(5-6)}$ has contributed to the visibility of mental health demands and influenced the development of research in this area. Studies have shown the variety of compositions and interactions between mental health services in each locality. As the network is woven into the daily routine of services and in relationships between structures and social agents, workers and managers play a fundamental role in mobilizing resources to meet users' demands ${ }^{(7-10)}$.

Different researchers have highlighted that psychosocial care is not limited to specialized mental health services and involves building relationships with health institutions and other sectors in order to put into practice the psychosocial rehabilitation and insertion into territories $\mathrm{s}^{(1,4,8,11-12)}$.

The articulation of mental health services in the logic of networks has been the object of several studies ${ }^{(1,4,13-22)}$. Despite the recognized importance of normative definitions, decrees and ordinances for composing the Psychosocial Care Network ${ }^{(8,9,19)}$, the differentiation and relationships between the scientific field and the bureaucratic field ${ }^{(23)}$ must be highlighted, as well as the influences of relations, conflicts and tensions between the various social agents in the daily routine of services ${ }^{(7,9,19)}$.

Studies have been developed from documentary analysis and/or interviews with managers and professionals of specific categories ${ }^{(1,4,13-20)}$, but only two studies involved different professional categories. One of them was performed with workers and managers of Type III Psychosocial Care Centers of the state of São Paulo(21) and the other with higher level professionals from various points of the Psychosocial Care Network in the western region of São Paulo ${ }^{(22)}$. Thus, this study is justified by the need to address the various points of the municipal care network in order to produce evidence on how the Psychosocial Care Network has been implemented in different locations. It is about the sedimentation of studies related to the constitution of the psychosocial field, and the capture of relations between network structures and the mediations performed by social agents.

In this regard, the framework of Pierre Bourdieu's constructionist structuralism ${ }^{(24-25)}$ was adopted to delineate the guiding question of the study 'What is the perception of workers and managers about the psychosocial care network of a mediumsized municipality in the inlands of the state of Minas Gerais?'

\section{OBJECTIVE}

To analyze the perception of workers and managers about the Psychosocial Care Network in a medium-sized municipality in the inlands of the state of Minas Gerais.

\section{METHOD}

\section{Ethical aspects}

The project was approved by the Research Ethics Committee and complied with the ethical precepts recommended by Resolution number 466/2012 of the National Health Council. Participants signed an informed consent form and received a copy of it. Each participant was identified by a number to ensure anonymity.

\section{Theoretical framework and type of study}

This is a qualitative, descriptive and exploratory study in which Pierre Bourdieu's constructionist structuralism was adopted as a theoretical framework. This approach recognizes the existence in the social world of "objective structures, independent of agents' consciousness and willingness that can guide or coerce their practices and representations". At the same time, there is "a social genesis of the schemes of perception, thought and action that constitute the [...] habitus and, on the other, there are social structures, in particular [...], of fields and groups [...]"(24).

According to Bourdieu ${ }^{(25)}$, the adoption of the habitus construct derived from his interest in breaking with structuralism without falling into subjectivism. Habitus is understood as "a system of durable and transposable dispositions which, by integrating all past experiences, functions, at each moment, as a matrix of perceptions, appreciations, and actions"(26). Such a system is updated and recomposed at each moment and implemented in specific fields.

The fields are understood as a field of forces, of battles fought sometimes for their transformation, sometimes for their reproduction. The allocation of specific capital of/in the field will conform its structure ${ }^{(27)}$. Thus, understanding the field of psychosocial care contributes significantly to the analysis of managers and workers' perception about the Psychosocial Care Network in the municipality studied and more specifically, to the delineation of tensions in this field.

The plurality of capitals is emphasized by Bourdieu, who presents the economic, cultural, social and symbolic capitals. All agents, in their path of training, performance and economic condition, elaborate their capitals, from which we can understand the positions taken over in the field ${ }^{(28)}$. The capitals of agents of the present study come from different spaces and express the way they fit into social reality, groups and institutions. In turn, the perception about the network is related to these agents' capitals and their positions in the psychosocial field ${ }^{(26)}$.

In line with the adopted theoretical framework, we sought to identify the matrix of perceptions of social agents, which guides their representations of the Psychosocial Care Network, and their actions in the field of psychosocial practice (habitus and objective structures). In the exercise of this analysis, were considered the relationships and tensions in the field, from which we sought to identify the disposition of these social agents in relation to the reproduction of the status quo or transformation of their practices. 


\section{Study scenario}

The medium-sized municipality in the inlands of Minas Gerais was intentionally selected because of the implementation of substitutive services already in the 1990s and the diversity of points of the care network. The municipality had two Type II Psychosocial Care Centers (CAPS III) - one municipal and one philanthropic; a Child and Youth Psychosocial Care Center (CAPSi); one Type III Alcohol and Drugs Psychosocial Care Center (CAPS Ad III); a Psychiatric Hospital (HP); a team from the Street Office Program (CR); a team of the Mental Health Matrix Strategy (MSM); five Therapeutic Residence Services (SRT), of which three municipal and two philanthropic.

\section{Data source}

The eligibility criteria were to work as manager or technical reference at any point of the Psychosocial Care Network and be in the exercise of these duties during the study period. Exclusion criteria were being away from work at the time of data collection due to sick leave or vacation.

There were nine managers at the time of data collection, namely: one director of Psychosocial Care, three managers of municipal Psychosocial Care Centers; two managers of the philanthropic Psychosocial Care Center - one administrative worker and one clinical worker; a manager of the Psychiatric Hospital; a manager of the three municipal Therapeutic Residence Services; a manager of the two philanthropic Therapeutic Residence Services. As the staff of the Street Office program and the Mental Health Matrix Strategy did not have managers, the social worker and the nurse of the Street Office program and the psychiatrist of the Mental Health Matrix Strategy were interviewed. Twelve workers were eligible to participate, and all joined the study. Table 1 presents the profile of participants.

Table 1 - Participants of the study according to education, working time in mental health and in the institution, Municipality of the inlands of Minas Gerais, Brazil, 2017 ( $n=12)$

\begin{tabular}{|c|c|c|c|c|c|}
\hline & Institution & Degree & $\begin{array}{l}\text { Postgraduate } \\
\text { degree }\end{array}$ & $\begin{array}{l}\text { Working } \\
\text { time in } \\
\text { mental } \\
\text { health } \\
\text { (years) }\end{array}$ & $\begin{array}{c}\text { Working } \\
\text { time in the } \\
\text { institution } \\
\text { (years) }\end{array}$ \\
\hline E1 & DAPS & Psychology & Specialist & 7 & 4 \\
\hline E2 & CAPSi & Psychology & Specialist & 16 & 16 \\
\hline E3 & CAPS II & Social Service & Specialist & 21 & 21 \\
\hline E4 & CAPS-ad & Psychology & Specialist & 21 & 16 \\
\hline E5 & $\mathrm{CR}$ & Nursing & Specialist & 4 & 4 \\
\hline E6 & $\mathrm{CR}$ & Social Service & Specialist & 4 & 4 \\
\hline E7 & MSM & Medicine & $\begin{array}{l}\text { Specialist and } \\
\text { Master's student }\end{array}$ & 5 & 4 \\
\hline E8 & SRT & Nursing & Specialist & 4 & 4 \\
\hline E9 & CAPS II & Psychology & Specialist and Master's & 25 & 25 \\
\hline E10 & CAPS II & Medicine & Specialist & 26 & 25 \\
\hline E11 & SRT & Nursing & No specialization & 5 & 5 \\
\hline E12 & Hosp. Psiq. & Social Service & Master's and PhD & 14 & 14 \\
\hline
\end{tabular}

DAPS-Psychosocial Care Board; CAPSi-Child and Youth Psychosocial Care Center; CAPSII-Typell Psychosocial CareCenter; CAPS-Ad-Alcohol andDrugs Psychosocial CareCenter; CR-Street OfficeProgram; MSM - Mental Health Matrix Strategy; SRT - Therapeutic Residence Service; HP-Psychiatric Hospital.

\section{Data collection and organization}

Recruitment of participants took place at their workplace. Data collection was performed through semi-structured interviews. The guiding questions were: What are the services offered in the institution? In your opinion, does the network offer the necessary conditions for the care of people with mental disorders and their families? How do you understand the challenges faced by the institution and by the Psychosocial Care Network?

The interviews were conducted by the lead researcher - who has a degree in Social Sciences, a PhD in Sociology and experience in qualitative research - in places defined by participants with conditions of confidentiality and privacy. The average duration of interviews was ninety minutes. After transcription, the audios were deleted. A copy of the transcript was delivered to each person involved, which is one of the requirements for the rigor of qualitative research ${ }^{(29)}$. No entries or deletions of information were requested by respondents.

\section{Data analysis}

Pierre Bourdieu's framework of constructionist structuralism was used for the analysis focused on capturing the multiple relationships and positions taken over by the study participants in the psychosocial field and how they interact with other fields.

The process of data interpretation and analysis was conducted based on the structuralist research protocol ${ }^{(28)}$, according to which it is necessary to understand the structuring of the field where social agents build their perceptions and position themselves. Initially, the composition of the Psychosocial Care Network of the municipality of Minas Gerais was outlined. The Psychosocial Care Network was considered as the field from which were captured the habitus and capital expressed by the social agents. Based on the positions of study participants, were outlined the relationships of institutions of Psychosocial Care Network with one another, and with other institutions.

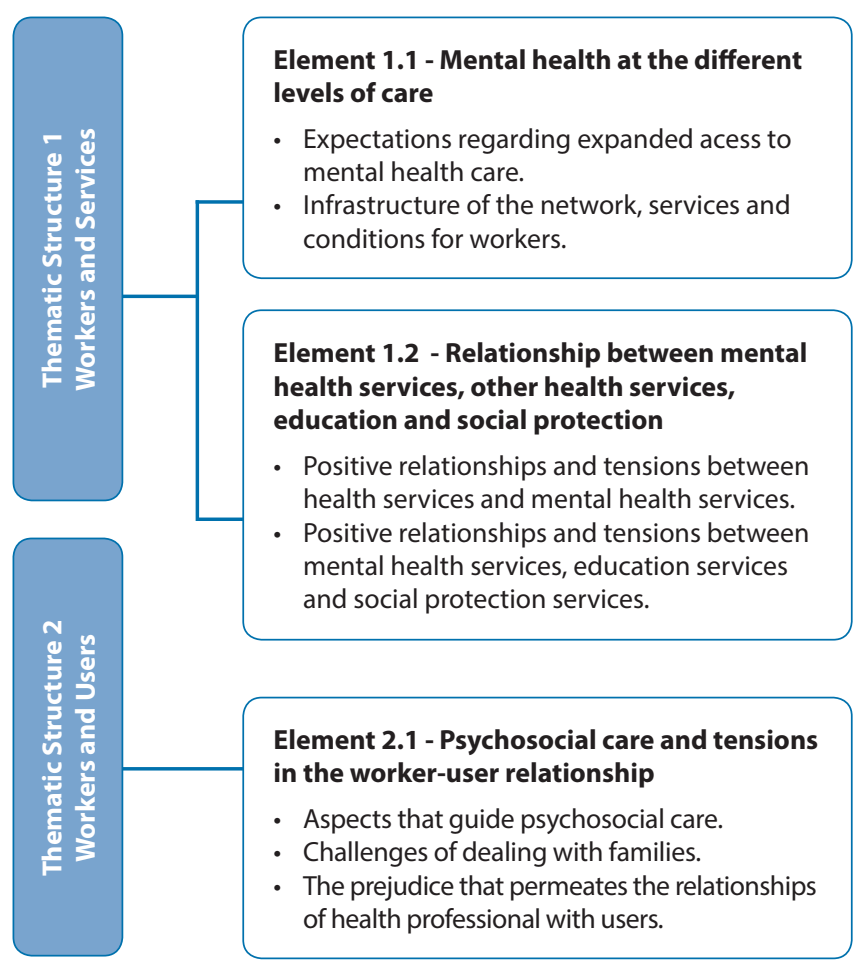

Figure 1 - Thematic structures, elements and results 
The lead researcher performed successive readings of the transcripts and highlighted recurring topics and themes. After completing the individual readings, the convergences and divergences identified were jointly evaluated in order to delineate a group of relationships between the elements for the development of thematic structures. At the end of this process, two thematic structures were defined: workers and services; workers and users (Figure 1).

\section{RESULTS}

The thematic structures and main results are presented in Figure 1.

\section{Thematic structure 1 - Workers and services}

\section{Element 1.1-Mental health at the different levels of care}

The results contemplated here relate to how participants understand mental health in the Psychosocial Care Network, the expectations regarding expanded access to care, and challenges related to the network consolidation. Overall, participants mentioned mental health actions at the different levels of care, despite the still prevailing idea that mental health demands should be met only in specialized services:

[The] health care unit does not provide care because there they say:

- Look, mental illness is not in our scope, because we have no psychiatrist. (E12 HP)

It's a network still with a culture of specialized care, focused very much on Psychosocial Care Centers and the Psychiatric Hospital. [...] (E1 DAPS)

The matrix strategy and training of primary care teams were mentioned as efforts to fulfill these demands, with expectations regarding the expansion of mental health actions in primary care:

[...] there are 51 Family Health teams [...] there is the matrix strategy in $50 \%$ of primary care units [...] these teams were trained in mental health issues, raised the demands of the territory and perform follow-up. (E1 DAPS)

[...] one thing that happened in mental health that I thought fantastic and it was always our dream: the gradual insertion into primary care. [...] It is not yet having the effects / would expect, but [...] it will have results soon. (E12 HP)

In basic care [...] there is a little more information about the role of mental health in health [...] this has led to improvements in care offer. (E4 Ad)

Regarding the infrastructure of services, participants mentioned some difficulties related to the Psychosocial Care Center and Therapeutic Residence Services, and indicated the lack of components related to leisure and reintegration at work:

[...] what would be a challenge for us, is a proper place. (E2 CAPSi)

For being a therapeutic residence, there is lack of many house things. (E8 SRT)
[...] deficits in the field of leisure, there is no community center in the city, there is no solidarity economy network, psychosocial rehabilitation. [...] I think it should be reorganized, and this reorganization involves fighting for community centers, social cooperatives, in the field of leisure, work and the field of clinic [...]. (E10 CAPS)

Regarding urgency and emergency care, respondents highlighted aspects that need improvement:

Psychiatric and child-youth urgency and emergency care are the most deficient services. What we feel is more lacking is this part of psychiatric urgency [...] a space for the embracement of psychiatric urgency patients. (E8 SRT)

Regarding workers' conditions, the need for more qualification and the issue of remuneration were mentioned:

We have been working like warriors, because we earn very little, we face a heavy workload to serve a difficult to manage population [...]. (E12 HP)

[...] advances are needed in the team qualification [...] the permanence of these professionals and the qualification greatly determine how this network will work [...]. (E12 HP)

\section{Element 1.2 - Relations between mental health services, other health services, education and social protection}

The results on participants' perception of the relationship between mental health services and other health services are described in figure 2, which was prepared from the perspective ${ }^{(30-31)}$ of social network mapping.

The following statements illustrate the relationships presented in figure 2. Interactions between Family Health team professionals and Therapeutic Residences were described as follows:

The Family Health team doctor comes here, the nurse, community agent, the dentist comes here, they brush patients' teeth, do the mouthwash program with residents, do the treatment [...]. (E8 SRT)

The outpatient clinics were highlighted as less integrated with other network services.

[...] in the electronic waiting list, after five months, we don't even find the user anymore. [...] Then, he [homeless person] will have given up treatment. (E5 CR)

[...] if I discharge the patient [...] he will be treated only 40 days from now, his prescription will be expired, he will not have access to medication, and we know what happens [...] (E12 HP)

The relationships established between the various Psychosocial Care Centers, and between these and other mental health institutions were also cited. Some resources that facilitate the articulation between services were mentioned:

[...] patients who are still hospitalized at the mental institution come to the Psychosocial Care Center for screening before leaving the mental institution. [...] they come to know the service, know the professionals [...] to leave there and already be familiar. (E3 CAPS) 


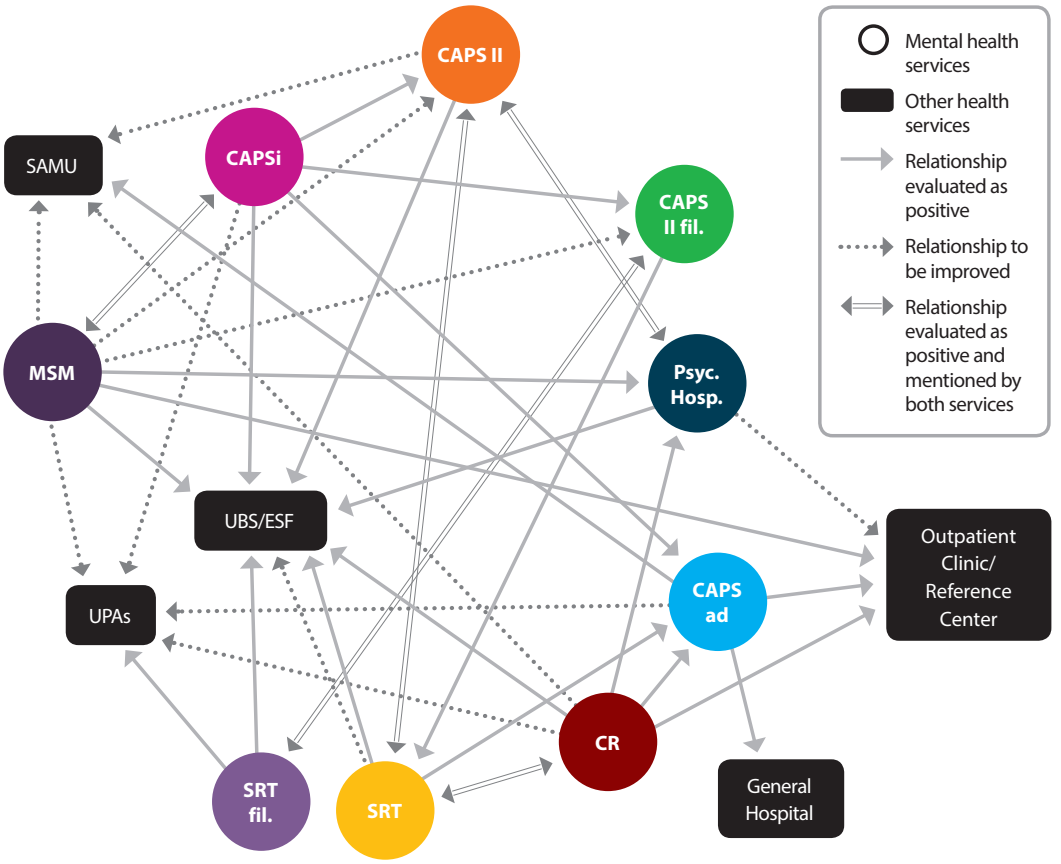

Subtitle: CAPSi - Child and Youth Psychosocial Care Center; CAPS II - Type II Psychosocial Care Center; CAPS - Ad - Alcohol and Drugs Psychosocial Care Center; CR - Street Office Program; ESF - Family health team; MSM - Mental Health Matrix Strategy; SAMU - Emergency mobile care service; SRT - Therapeutic Residence Service; Hosp. Psiq. - Psychiatric Hospital; UPA - Emergency care unit; UBS- Basic health unit.

Figure 2 - Relationships established between mental health services and other health institutions as mentioned by participants. Municipality of the inlands of Minas Gerais, Brazil, 2017 ( $n=12$ )

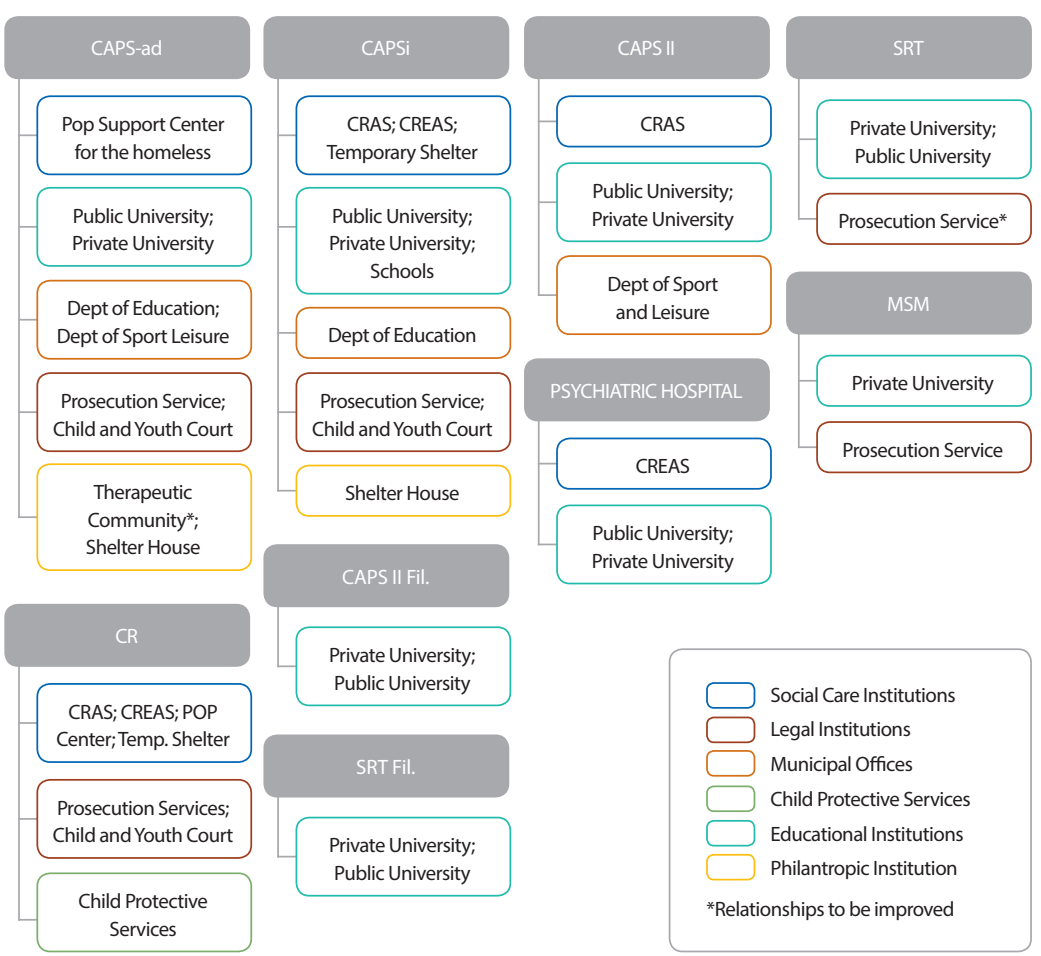

Subtitle: CAPSi - Child and Youth Psychosocial Care Center; CAPS II - Type II Psychosocial Care Center; CAPS - Ad - Alcohol and Drugs Psychosocial Care Center; MSM - Mental Health Matrix Strategy; SRT - Therapeutic Residence Service; Fil. Philantropic institution; CRAS - Reference Center for Social Assistance; CREAS- Reference Center Specialized in Social Assistance; Dept. - Department.

Figure 3 - Institutions and/or components with which mental health services articulate, according to interviewees, Municipality of the inlands of Minas Gerais, Brazil, 2017 ( $n=12$ )
[...] we have access to SUS-Fácil [care regulation software of the National Health System] and from here we ask for a bed at the state level [...] the doctor can contact the [general hospital] and make referrals from here, if necessary. (E4 Ad)

Figure 3 presents the relationships of mental health services with legal, education and social protection institutions, as reported by study participants.

The statements below illustrate some interlocutions with leisure and social protection institutions mentioned by participants.

[...] once a month, they [CAPS-Ad users] watch a movie there at the theater. (E4 Ad)

[...] when I have a demand from a boy from the neighborhood, we seek the Reference Centerfor Social Care [CRAS], seek the Reference Center Specialized in Social Care [CREAS], ask for help, request, give feedback. (E2 CAPSi)

[...] if the user has a child on the street [...] we ask the Prosecution Service for a basic documentation of these users [...] [PSR]. (E6 CR)

\section{Thematic structure 2- Workers and users}

\section{Element 2.1 Psychosocial care and tensions in the worker-user relationship}

Respondents emphasized that user care is provided by multiprofessional teams with priority of group approaches and resocialization activities. They also mentioned user embracement, listening and establishing bonds as a priority in the care of users:

Most activities are done in groups [...] therapeutic groups [...], relapse prevention, twelve-step philosophy support group [...], resocialization activities outside the Psychosocial Care Center, visits to universities, parks, shopping, tours, museum [...]. (E4 Ad)

The service that aims at userembracement, listening, listening in every way, even listening to the silence, to the user's body and providing care for what he needs there. (E4Ad)

The way you receive the user, with neutral eyes [...] I need to see the user as a person [...]. (E2 CAPSi)

The psychiatric hospital manager described hospitalizations as "flexible" and aimed at reintegration into the network:

We provide care on a more flexible therapeutic plan, in the sense of a hospitalization that they call integral [...]. It is the withdrawn from the crisis, stabilization, referral to the mental health network for continuity of treatment in the outpatient system. (E12 HP) 
Actions related to health, recreation and daily organization were also mentioned as part of the psychosocial care offered by Therapeutic Residence Services:

[...] the occupational therapist goes once a week in each residence [...] the psychologist performs follow-up with the residents. Some other activities are performed by technicians at the residents' homes, some type of recreation. [...]. The nurses prepare all the medication prescribed for [...] administration by the technicians. (E8 SRT)

[...] [in the Therapeutic Residence Service] life and housing are organized. (E10 CAPS)

The logic of harm reduction was cited by the Street Office professional as part of the care for the homeless:

[...] we still do a little bit of harm reduction, offer guidance, provide condoms. [...] referrals for treatment of chemical dependence, mental health and insert these services that aremore of primary care [...]. (E6CR)

Families were recognized as part of psychosocial care for users. However, the challenge of including families in this care and the need to expand the work with them were emphasized. Another challenge mentioned was the tension between families and users themselves:

Care to the family is not easy, you know, because they don't come, it's not just up to us, there's no adherence of the family. (E2 CAPSi)

[...] a bit of this difficulty is to bring the family closer to treatment, to collaborate more, participate more in the reality of this treatment [...]. (E4 Ad).

Because by the ordinance of the Prosecution Service, the therapeutic residence would be for those who do not have family ties. These people have family here [...]. Their main reason for being in the Therapeutic Residence is by court order [...]. As the family does not want to care for them, the prosecution passes the torch to the municipality, to Residence Services. (E8 SRT)

Prejudice was mentioned as a barrier to the access to health services and social care:

A psychiatric urgency is the worst of all, because there is resistance from SAMU [mobile emergency care service] to provide transportation [...]. (E8 SRT)

[...] certain professionals do not even come close at the time of care. They prefer that the person accompanying them, the nursing technician or the nurse, tells everything that is happening to the resident. They do not listen to the resident [...]. (E8 SRT)

\section{DISCUSSION}

In light of Pierre Bourdieu's theoretical construct ${ }^{(26-27)}$ it was possible to capture the articulation between the various capitals of the social agents participating in the study. The cultural capital is a set of qualifications, knowledge and skills constructed by agents, in which different scientific areas that form the psychosocial field are articulated. As described in the results, the set of social accesses expressed in the variety of contacts and relationships of social agents was evident in the speeches of interviewees, who brought to light the relevance of this capital for the articulation of the various networks. The symbolic capital, in turn, refers to the recognition of these social agents expressed by the role played in institutions and programs, whether as managers or socially authorized professionals to speak on behalf of the service. The complexity and interaction of these capitals support these agents' representations of the psychosocial care network ${ }^{(26-27)}$.

As pointed out in the results, two major groups of relationships were identified from the perception of social agents: 1 ) of workers with services and 2) of workers with users. In the first group, terms such as partnership, support, co-participation, dialogue, good communication, joint discussions, assistance, asking for help, providing support, giving feedback, triggering, good relationship and participation in the therapeutic project give nuances to the matrix of perceptions that guide the professionals'representation of Psychosocial Care Networks in their municipality. As the orientation of agents' practices and representations is not exempt from the interests of the field, it is a fact that this predominantly positive perception about mental health in care services is crossed by different limits and challenges arising from the counter-hegemonic model proposed by the notion of psychosocial care.

Participants expressed their expectations of a broader access to mental health care, especially more mental health actions in primary care and optimism about the potentiality of this level for mental health. This perspective is consistent with the proposed network action, which values the specificities of each institution and service ${ }^{(2,4)}$. In addition, the strengthening of mental health in primary care is in line with the community approach and the perception of territories as an existential territory "that involves spaces constructed as material and affective elements of the environment, that when appropriated and managed expressively, constitute places to live ${ }^{\prime \prime(11)}$.

Such strengthening can also contribute to mobilize other community resources and expand the support network of users and families, which are fundamental for psychosocial rehabilita$\operatorname{tion}^{(32-33)}$. In the municipality studied, this insertion has occurred through the team of the Mental Health Matrix Strategy and the Family Health Strategy. Efforts to value and involve workers from Family Health Support Centers, Basic Health Units and matrix units are urgent to ensure the performance of different primary care workers in mental health care ${ }^{(13)}$.

Nevertheless, the emphasis on primary care as a key aspect for improving the Psychosocial Care Network and the criticism on the lack of some components suggest that participants improvement expectations are more focused on unconsolidated actions and services, and they have little consideration for the potential of improvements in their own locus of activity, which is essential to complement the network qualification.

The analysis also showed that the institutions establish deep relationships with other health services, education and social protection services that are essential for psychosocial rehabilitation. These relationships should be expanded by adding other territorial resources ${ }^{(8,32)}$. Most described relationships need improvement and outpatient clinics were identified as the least integrated in the network. It is worth highlighting the specificity of the outpatient work process to the detriment of Psychosocial Care Center proposals, highlighting the notion of "intensive" care 
and prioritization of social reintegration rather than a medicalizing approach focused exclusively on symptom reduction. Although outpatient clinics have different characteristics in relation to the psychosocial rehabilitation proposal, they have been the focus of recent policies ${ }^{(34)}$ that recommend their expansion and raise the issue of field strengths and disputes regarding transformations or reproductions of certain care models.

On the other hand, participants also reported some tensions regarding the network structure. In the perception of these agents, aspects such as low participation of some institutions/ components, poor communication between the elements that make up the structure, referrals and difficult access, barrier to the continuity of care and delay in counter-referral services outlined these tensions. However, the tensions mentioned were more related to service partners than to the own participant, suggesting again a tendency to understand that the network improvement depends more on external transformations than on the more effective disposition of one's own experiences.

In a previous study, poor communication and difficulties with the articulation between the various network services were identified as challenges of priority networks ${ }^{(6)}$. The literature has indicated the mobilization of light technologies as a possibility for the greater activation of institutions and monitoring of $\operatorname{cases}^{(9,35)}$.

Hence the importance of investments in workers' continuing education. According to study participants, there are resistances and barriers to the care of people with mental disorders in nonspecialized services, which strengthens the focus on specialties. The reports emphasized difficulties to meet urgent and emergency care, a topic addressed in other studies ${ }^{(10,36)}$. A study involving 156 workers from different regions of the country enrolled in the course "Crisis and Urgency in Mental Health", offered in partnership by a federal university and the Ministry of Health, revealed that care was provided primarily with drugs, mechanical containment and hospitalization ${ }^{(10)}$. This highlights the importance of strengthening the action in network and investing in continuing education to consolidate care and overcome the centrality of the psychiatric hospital in crisis management ${ }^{(10,36)}$. Nevertheless, previous studies have problematized the idea that the solution to most limitations in the field of mental health is training ${ }^{(22,37)}$, since even among some highly specialized teams, such limits are present.

As indicated in an international study, difficulties with attending stigma-related comorbidities have resulted in neglect of clinical demands and excess mortality of people with mental disorders, which is in flagrant disagreement with equity and human rights ${ }^{(38)}$.

A study conducted in the Brazilian context revealed the permanence of users in the Psychosocial Care Center for long periods, due to the few opportunities for insertion in institutions and services, which indicates the importance of expanding community spaces ${ }^{(12)}$. The so-called "chronification" can contribute to problematize psychosocial rehabilitation, which is the objective to be achieved in an intersectoral way, with protagonism of users and their families ${ }^{(12)}$.

In this sense, the organization of services according to the logic of the territory has profound consequences not only for users'lives, but also for communities. It is about rehabilitating the territories in order to "collectively build new forms of living with difference"(11).

In the second group of relationships, tensions were also identified in the relationship between mental health professionals, families and users. The approach and involvement of families in the care process have been highlighted as important strategies for mental health care and the strengthening of policies and services $^{(39)}$. It is relevant to overcome disciplinary, control and tutelage strategies and foster their emancipation and autonomy ${ }^{(2,12,39)}$.

The prejudice of some professionals towards people with mental disorder was also emphasized. Barriers related to prejudice occur in many countries and are a challenge for access to health and the search for assistance. In a review study, were highlighted different types of stigmas, namely the perceived public stigma, personal attitudes toward members of a stigmatized group, internalized or anticipated stigma, and attitudes toward seeking help ${ }^{(40)}$. This typology is interesting to understand the findings of this study since, according to respondents, there are stigmas in the community, among health professionals, as well as in users' positions and attitudes. Identifying them can contribute to envision coping strategies ${ }^{(40)}$. Thus, the tensions and conflicts observed in the Psychosocial Care Network arising from the habitus and the positions of social agents represent possibilities for change ${ }^{(26-27)}$.

In contrast, the actions offered by services within a perspective of resocialization, user embracement, group and multiprofessional care, as well as approaches of harm reduction, recreation and daily organization, were the resources/capitals mentioned by participants. Such resources/capital are in line with the psychiatric reform $^{(41)}$ and demonstrate the search for sedimentation of the psychosocial care model ${ }^{(4)}$.

\section{Study limitations}

The collection of data with different interest groups, such as users and workers, would certainly enrich the list of results and enable the triangulation of perceptions, especially considering that within the psychosocial field, there is a variety of positions and wide differentiation of social agents. The involvement of managers and workers from institutions with which the various points of the Psychosocial Care Network articulate would contribute to broaden the intersectoral approach.

The choice of individual interviews can be considered as a limitation of the study design, because collective strategies for data construction would foster a joint reflection about the Psychosocial Care Network.

The data collection process preceded the mental health policy changes determined by the federal government ${ }^{(34)}$ that brought a lack of financing of community services and setbacks in relation to the care model, with emphasis on hospitalization. Therefore, participants' considerations about advances in the Psychosocial Care Network should be understood in context and referenced to the previous policy.

\section{Contributions to public mental health policy}

Although data collection has been delimited within the municipality, this study contributes to important reflections on relationships and tensions in the psychosocial field and may foster debates and action plans related to the optimization and strengthening of the Psychosocial Care Network.

One of the highlights of the study design were the contributions of Pierre Bourdieu's theoretical perspective for valuing the relationships between social agents and the structures of the Psychosocial Care Network in mental health care, and the importance of understanding the symbolic disputes in the psychosocial field ${ }^{(26-27)}$. 
The present study indicated relevant actions of psychosocial care improvements and recognized the legal advances in the last three decades. However, the model of care based on community services has experienced setbacks in relation to institutionalization ${ }^{(41)}$, which reinforces the existence of conflicts and tensions in the psychosocial field and in its relations with the health and social care fields $s^{(26-27)}$. Different perspectives are in conflict and dispute in the field and understanding them can contribute to advances in the care model.

\section{FINAL CONSIDERATIONS}

The study findings show that the perception matrix of participants originates from their position in the psychosocial field.
Since most of them are managers, it was somewhat expected there would be more references to positive aspects of the services where they work than to the existing limits. Most tensions and difficulties mentioned were related to services other than their own, especially to other sectors.

In general, the habitus of social agents was expressed much more by their disposition to transform than to reproduce the status quo. Such disposition was perceived in statements with expectation for the expansion of primary care actions and optimism about improvements in the Psychosocial Care Network. Social agents demonstrated disposition to contribute to change processes in order to overcome the focus on specialties, lack of training of some teams, and lack of infrastructure and some components, especially those related to leisure and community life.

\section{REFERENCES}

1. Diminic S, Carstensen G, Harris MG, Reavley N, Pirkis J, Meurk C, et al. Intersectoral policy for severe and persistent mental illness: review of approaches in a sample of high-income countries. Glob Ment Health [Internet]. 2015 [cited 2017 Dec 15];24(2):1-18. Available from: https:// www.ncbi.nlm.nih.gov/pmc/articles/PMC5269620/

2. World Health Organization. Mental Health Action Plan 2013-2020. Geneva: World Health Organization [Internet]. 2013 [cited 2017 Oct 2]. Available from: http://www.who.int/mental_health/action_plan_2013/en/

3. Vigo D, Thornicroft G, Atun R. Estimating the true global burden of mental illness. Lancet Psychiatry [Internet]. 2016 [cited 2018 Mar 9];3(2):171-8. Available from: http://www.thelancet.com/journals/lanpsy/article/PIIS2215-0366(15)00505-2/fulltext?showall=true=

4. Yasui S, Luzio CA, Amarante P. From manicomial logic to territorial logic: impasses and challenges of psychosocial care. J Health Psychol [Internet]. 2016 [cited 2018 Jun 10];21(3):400-8. Available from: http://journals.sagepub.com/doi/pdf/10.1177/1359105316628754

5. Ministério da Saúde (BR). Portaria n 3.088, de 23 de dezembro de 2011. Institui a Rede de Atenção Psicossocial para pessoas com sofrimento ou transtorno mental e com necessidades decorrentes do uso de crack, álcool e outras drogas, no âmbito do Sistema Único de Saúde (SUS) [Internet]. 2011 [cited 2017 Dec 10]. Available from: http://bvsms.saude.gov.br/bvs/saudelegis/gm/2011/prt3088_23_12_2011_rep.html

6. Ministério da Saúde (BR), Secretaria de Atenção à Saúde. Implantação das redes de atenção à saúde e outras estratégias da SAS [Internet]. Brasília: Ministério da Saúde; 2014 [cited 2018 Mar 10]. Available from: http://bvsms.saude.gov.br/bvs/publicacoes/implantacao_redes_ atencao_saude_sas.pdf

7. Quinderé PHD, Jorge MSB, Franco TB. Rede de atenção psicossocial: qual o lugar da saúde mental? Physis [Internet]. 2014 [cited 2018 Mar 10];24(1):253-71. Available from: http://www.scielo.br/pdf/physis/v24n1/0103-7331-physis-24-01-00253.pdf

8. Eslabão AD, Coimbra VCC, Kantorski LP, Pinho LB, Santos EO. Mental health care network: the views of coordinators of the Family Health Strategy (FHS). Rev Gaúch Enferm [Internet]. 2017 [cited 2018 Mar 10];38(1):1-8. Available from: http://www.scielo.br/pdf/rgenf/v38n1/01026933-rgenf-1983-144720170160973.pdf

9. Bermudez KM, Siqueira-Batista R. "Many holes tied together with ropes": the concept of network for mental health professionals. Saúde Soc [Internet]. 2017 [cited 2018 Jan 10];26(4):904-19. Available from: http://www.scielo.br/pdf/sausoc/v26n4/1984-0470-sausoc-26-04-904.pdf

10. Zeferino MT, Cartana MHF, Fialho MB, Huber MZ, Bertoncello KCG. Health workers' perception on crisis care in the Psychosocial Care Network. Esc Anna Nery[Internet]. 2016 [cited 2018 Aug 07];20(3):e20160059. Available from: http://www.scielo.br/pdf/ean/v20n3/14148145-ean-20-03-20160059.pdf

11. Lima EMF, Yasui S. Territories and meanings: space, culture, subjectivity and care in psychosocial attentiveness. Saúde Debate [Internet]. 2014 [cited 2018 Mar 20];38(102): 593-606. Available from: http://www.scielo.br/pdf/sdeb/v38n102/0103-1104-sdeb-38-102-0593.pdf

12. Moreira MIB, Onocko-Campos RT. Mental health care actions in the psychosocial care network viewed by users. Saúde Soc [Internet]. 2017 [cited 2017 Jun 10];26(2):462-74. Available from: http://www.scielo.br/pdf/sausoc/v26n2/1984-0470-sausoc-26-02-00462.pdf

13. Trapé TL, Onocko-Campos R. Modelo de atenção à saúde mental do Brasil: análise do financiamento, governança e mecanismos de avaliação. Rev Saúde Pública [Internet]. 2017 [cited 2017 Dec 10];51(19):1-8. Available from: http://www.scielo.br/pdf/rsp/v51/pt_00348910-rsp-S1518-87872017051006059.pdf

14. BrookeSumner C, Lund C, Petersen I. Bridging the gap: investigating challenges and way forward for intersectoral provision of psychosocial rehabilitation in South Africa. Int J Mental Health Sys [Internet] 2016 [cited 2019 Sep 02];10:21. Available from: https://www.ncbi.nlm.nih. gov/pmc/articles/PMC4784432/pdf/13033_2016_Article_42.pdf

15. Saymah D, Tait L, Michaeil M. An overview of the mental health system in Gaza: an assessment using the World Health Organization's Assessment Instrument for Mental Health Systems (WHO-AIMS). Int J Mental Health Sys[Internet] 2015 [cited 2019 Sep 02];9:4. Available from: https://www.ncbi.nlm.nih.gov/pmc/articles/PMC4361134/pdf/13033_2014_Article_217.pdf 
16. Santos P, Wainberg ML, Caldas-de-Almeida JM, Saraceno B, Mari JJ. Overview of the mental health system in Mozambique: addressing the treatment gap with a task-shifting strategy in primary care, Int J Mental Health Sys[Internet] 2016 [cited 2019 Sep 02];10:1 Available from: https://ijmhs.biomedcentral.com/track/pdf/10.1186/s13033-015-0032-8?site=ijmhs.biomedcentral.com

17. Dantas CR, Oda AMGR. Cartografia das pesquisas avaliativas de serviços de saúde mental no Brasil (2004-2013). Physis [Internet] 2014 [cited 2019 Sep 02];24(4):1127-9. Available from: http://www.scielo.br/pdf/physis/v24n4/0103-7331-physis-24-04-01127.pdf

18. Costa PHA, Colugnati FAB, Ronzani TM. Avaliação de serviços em saúde mental no Brasil: revisão sistemática da literatura. Ciênc Saúde Coletiva [Internet] 2015 [cited 2019 Sep 02];20(10):3243-53. Available from: http://www.scielo.br/pdf/csc/v20n10/1413-8123-csc-20-10-3243.pdf

19. Paes LG, Schimith MD, Barbosa TM, Righi LB. Rede de atenção em saúde mental na perspectiva dos coordenadores de serviços de saúde. Trab Educ Saúde [Internet] 2013 [cited 2019 Sep 02];11(2):395-409. Available from: http://www.scielo.br/pdf/tes/v11n2/a08v11n2.pdf

20. Valentine A, DeAngelo D, Alegría M, Cook BL. Translating disparities research to policy: a qualitative study of state mental health policymakers' perceptions of mental health care disparities report cards. Psychol Serv[Internet]. 2014 [cited 2019 Sep 02];11(4):377-87. Available from: https://www.ncbi.nlm.nih.gov/pmc/articles/PMC4228957/pdf/nihms628513.pdf

21. Furtado JP, Onocko-Campos RT, Moreira MIB, Trapé TL. A elaboração participativa de indicadores para a avaliação em saúde mental. Cad Saúde Pública [Internet]. 2013 [cited 2019 Sep 02];29( 1 ): 102-110. Available from: http://www.scielo.br/pdf/csp/v29n1/12.pdf

22. Nóbrega MPSS, Domingos AM, Silveira ASA, Santos JC. Tecendo a Rede de Atenção Psicossocial Oeste do município de São Paulo. Rev Bras Enferm [Internet]. 2017 [cited 2019 Oct 10];70:5. Available from: http://www.scielo.br/pdf/reben/v70n5/0034-7167-reben-70-05-0965.pdf

23. Furtado JP, Oda WY, Borysow IC, Kapp S. The concept of territory in Mental Health. Cad. Saúde Pública [Internet]. 2016 [cited 2019 Nov 12]; 32:9. Available from: http://www.scielo.br/pdf/csp/v32n9/en_1678-4464-csp-32-09-e00059116.pdf

24. Bourdieu P. Coisas ditas. São Paulo: Brasiliense; 2004. Espaço social e poder simbólico; p. 149-68.

25. Bourdieu P. O poder simbólico. 11ed. Rio de Janeiro: Bertrand Brasil; 2007.

26. Bourdieu P. Esboço de uma teoria da prática. In: Ortiz R, organizador. Pierre Bourdieu: sociologia. São Paulo: Ática; 1983. p. 46-81.

27. Bourdieu P. Os usos sociais da ciência: por uma sociologia clínica do campo científico. São Paulo: UNESP; 1997.

28. Thiry-Cherques HR. Métodos estruturalistas: pesquisa em ciências da gestão. São Paulo: Atlas; 2008.

29. Tong A, Sainsbury P, Craig J. Consolidated criteria for reporting qualitative research (COREQ): a 32-item checklist for interviews and focus groups. Int J Qual Health Care [Internet]. 2007 [cited 2018 Abr 10];19(6)1:349-57. Available from: https://academic.oup.com/intqhc/ article/19/6/349/1791966

30. Campbell WM, Dagli CK, Weinstein CJ. Social network analysis with content and graphs. Lincoln Lab J[Internet]. 2013 [cited 2019 Oct 10];20(1):61-81. Available from: https://www.ll.mit.edu//publications/journal/pdf/vol20_no1/20_1_5_Campbell.pdf

31. Gomide M, Schütz GE. Social Network Analysis and assessment practices: challenges in sight. Physis. 2015;25(3):819-42. doi: 10.1590/ S0103-73312015000300008

32. Olschowsky A, Wtzel C, Schneider JF, Pinho LB, Camatta MW. Evaluation of intersectoral partnerships for mental healthcare in the brazilian family health strategy. Texto Contexto Enferm [Internet]. 2014 [cited 2018 Mar 20];23(3):591-9. Available from: http://www.scielo.br/pdf/tce/ v23n3/pt_0104-0707-tce-23-03-00591.pdf

33. Souza J, Assad FB, Barbosa SP, Badagnan HF, Almeida LY, Garla, CC. Mental health care situations in family health units: perception of community health agents. Texto Contexto Enferm [Internet]. Mar 2015 [cited 2018 Mar 20];24(1):204-11. Available from: http://www.scielo. br/pdf/tce/v24n1/pt_0104-0707-tce-24-01-00204.pdf

34. Comissão Intergestores Tripartite (CIT). Resolução ${ }^{3}$ 32, de 14 de dezembro de 2017. Estabeleceu as Diretrizes para o fortalecimento da Rede de Atenção Psicossocial (RAPS). Diário Oficial da União 2017; 22 dez.

35. Yoshiura VT, Azevedo-Marques JM, Rzewuska M, Vinci ALT, Sasso AM, Miyoshi NSB. A web-based information system for a regional public mental healthcare service network in Brazil. Int J Ment Health Syst [Internet]. 2017 [cited 2017 Dec 19];11:1-10. Available from: https://ijmhs. biomedcentral.com/articles/10.1186/s13033-016-0117-z

36. Dimenstein MDB, Gruska V, Leite JF. Psychiatric crisis management in the emergency care hospital network. Paidéia [Internet]. 2015 [cited 2018 May 10];25(60):95-104. Available from: http://www.scielo.br/pdf/paideia/v25n60/1982-4327-paideia-25-60-0095.pdf

37. Campos DB, Bezerra IC, Jorge MSB. Mental health care technologies: Primary Care practices and processes. Rev Bras Enferm [Internet]. 2018 [cited 2019 Oct 10];71(Suppl 5):2101-8. [Thematic Issue: Mental health] doi: http://dx.doi.org/10.1590/0034-7167-2017-0478

38. Saxena S. Excess mortality among people with mental disorders: a public health priority. Lancet Public Health [Internet]. 2018 [cited 2018 Jul 20];3(6):264-5. Available from: https://www.thelancet.com/pdfs/journals/lanpub/PIIS2468-2667(18)30099-9.pdf

39. Semrau M, Lempp H, Keynejad R, Evans-Lacko S, Mugisha J, Raja S, et al. Service user and caregiver involvement in mental health system strengthening in low- and middle-income countries: systematic review. BMC Health Serv Res [Internet]. 2016 [cited 2018 Ago 07];16:79. Available from: https://www.ncbi.nlm.nih.gov/pmc/articles/PMC4774091/pdf/12913_2016_Article_1323.pdf

40. Schnyder N, Panczak R, Groth N, Schultze-Lutter F. Association between mental health-related stigma and active help-seeking: systematic review and meta-analysis. Br J Psychiatry [Internet]. 2017 [cited 2017 Dec 10];210(4):261-8. Available from: https://doi.org/10.1192/bjp.bp.116.189464

41. Amarante $P$, Nunes MO. Psychiatric reform in the SUS and the struggle for a society without asylums. Ciênc Saúde Colet [Internet]. 2018 [cited 2018 Jul 09];23(6):2067-74. Available from: https://www.scielosp.org/pdf/csc/2018.v23n6/2067-2074/pt 